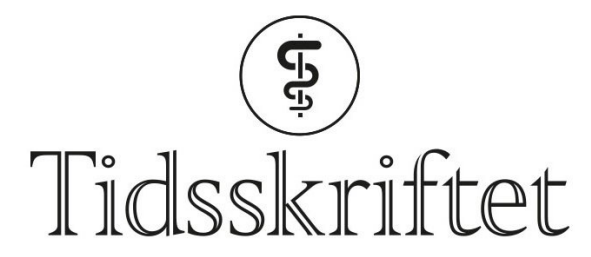

DEN NORSKE LEGEFORENING

\title{
Forside nr. 16/2019
}

FORSIDE

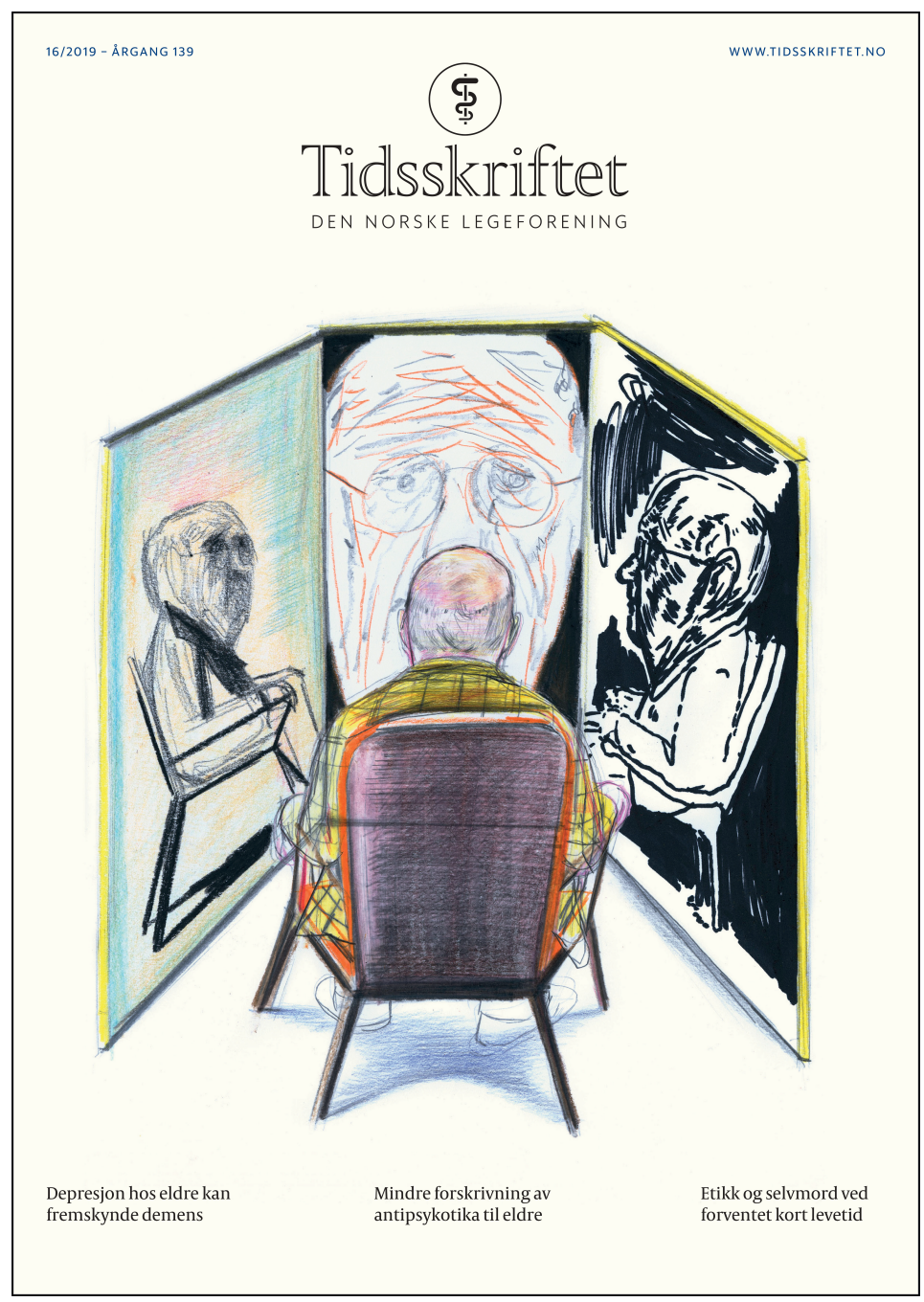

Illustrasjon (C) Yann Kebbi

Psykoterapi og støttesamtaler har god effekt hos eldre pasienter med depresjon. Det er ikke så rart når ensomhet og isolasjon er viktige disponerende faktorer. Likevel får eldre pasienter kanskje mer piller enn tid? Dette til tross for at eldre har mer og mer alvorlige bivirkninger av psykofarmaka og at risikoen for interaksjoner øker hos multimorbide pasienter med lange medikamentlister. Er samtaleterapi forbeholdt dem som skal tilbake i arbeid? Forsiden til denne utgaven er det Yann Kebbi som står bak. Mer av hans arbeider finner du her: https://www.yannkebbi.fr/ 
Publisert: 4. november 2019. Tidsskr Nor Legeforen. DOI: 10.4045/tidsskr.19.16.02 (C) Tidsskrift for Den norske legeforening 2020. Lastet ned fra tidsskriftet.no 